\title{
21. PALEOMAGNETISM OF THE CRETACEOUS/TERTIARY BOUNDARY, DEEP SEA DRILLING PROJECT LEG 77, SOUTHEASTERN GULF OF MEXICO1
}

\author{
Margaret M. Testarmata, Institute for Geophysics, University of Texas, Austin, Texas \\ and \\ Wulf A. Gose, Department of Geological Sciences and Institute for Geophysics, University of Texas, Austin, Texas
}

\begin{abstract}
At DSDP Sites 536 and 538 in the southeastern Gulf of Mexico, rocks from near the Cretaceous/Tertiary boundary were recovered. The Danian/Maestrichtian samples from Site 536 were stepwise demagnetized in alternating fields up to $400 \mathrm{Oe}$. Two distinct components of magnetization could be identified, neither of which displays a reversal pattern compatible with the age of the samples. Samples from the Danian section at Site 538 were subjected to a combination of alternating field and thermal demagnetization. Although several reversals are observed, a unique correlation with the magnetic time scale is not possible until the paleontology of the section is better defined.
\end{abstract}

\section{INTRODUCTION}

During the past several years, the Cretaceous/Tertiary boundary has been the subject of intensive research and controversy (Alvarez et al., 1980). Paleomagnetism has played a central role in this context because it has permitted correlation between geologic sequences with no common fauna. The magnetostratigraphy of the Cretaceous/ Tertiary boundary has been examined at several localities: a pelagic carbonate sequence in Gubbio, Italy (Roggenthen and Napoleone, 1977); terrestrial sequences in the San Juan Basin, New Mexico (Lindsay et al., 1981) and Red Deer Valley, Alberta (Lerbekmo et al., 1979); and at various DSDP sites, e.g., Sites 384 (Larson and Opdyke, 1979; Thierstein and Okada, 1979), 524 (Hsü, LaBrecque et al., in press), and 527 (Moore, Rabinowitz, et al., in press). Agreement between the studies is very good, but minor discrepancies do exist.

On DSDP Leg 77, cores from this time period were recovered at two sites: 536 and 538. At the former, the Cretaceous/Tertiary boundary was recorded by a continuous sequence of Danian and Maestrichtian ooze, chalk, and limestone. At Hole 538A, only the Danian was represented, by $2.1 \mathrm{~m}$ of recovered chalk.

\section{SHIPBOARD WORK}

From Site 536, Sections 536-9-3 through 536-9-6, 32 oriented samples were collected at approximately $15 \mathrm{~cm}$ spacing. Due to the soft nature of the sediment, all but two of the samples were collected by pressing $1 \mathrm{in}$. plastic boxes into the ooze. Little drilling disturbance was observed, but, as a precaution, samples were taken from the center of the split core, and sampling was avoided at depths where color banding, suggesting of bedding, was not horizontal. The two oldest samples were minicored from a graded, laminated limestone.

\footnotetext{
${ }^{1}$ Buffler, R. T., Schlager, W., et al., Init. Repts. DSDP, 77: Washington (U.S. Govt. Printing Office).
}

The natural remanent magnetization (NRM) was measured with a Digico magnetometer aboard the Glomar Challenger. Repeat measurements of NRM two days later showed that the magnetization of many samples had changed dramatically in direction and decreased in intensity, indicating that the samples can readily acquire a viscous component of magnetization. To avoid the possible viscous effect of the ambient field of the ship (1 Oe) and also because many samples had NRM intensities close to the noise level of the shipboard magnetometer, no further measurements were carried out during the cruise.

At Site 538, the Danian chalk (Sections 538A-20-4 through 538A-20-6) is sandwiched between Eocene rocks and topped by a hardground, implying that it is a slump block that was already lithified at the time of slumping. The bedding is nearly horizontal and the foraminiferal zones are in correct biostratigraphic sequence. The magnetic polarity determinations should therefore be correct, although the inclinations may differ slightly from their original values due to tilting. The bottom $30 \mathrm{~cm}$ in Section 538A-20-5 could not be sampled because it had been assigned in its entirety for organic geochemistry studies. Within the remaining Danian section, 11 oriented samples were minicored at $15-25 \mathrm{~cm}$ intervals. Low intensities of magnetization precluded measurements with the shipboard Digico magnetometer. An additional five samples were collected postcruise to complement the data derived from minicores obtained on the ship; in all, 16 samples were analyzed for this section.

\section{LABORATORY PROCEDURE}

All samples were measured postcruise with a cryogenic magnetometer at the University of Texas Institute for Geophysics. Prior to and during the measurements, samples were stored in a magnetically shielded room whose ambient field was approximately 100 gammas. Alternating field (AF) demagnetization was conducted with a Schonstedt single-axis demagnetizer in three orthogonal directions. Thermal demagnetization was performed in air, and the desired temperature was maintained for $10 \mathrm{~min}$. before the samples were cooled in a field of less than 5 gammas. 


\section{SITE 536}

\section{Results}

After the NRM was remeasured at the shore-based laboratory, all samples from Site 536 were demagnetized in peak alternating fields of $25,50,75,100,150,200$, 300 , and 400 Oe. Most samples responded to demagnetization in a very similar manner, suggesting a homogenous lithology. The intensities of magnetization, which averaged $2.66 \times 10^{-6} \mathrm{emu} / \mathrm{cm}^{3}$ for NRM, decreased as a tight cluster upon progressive demagnetization (Fig. 1). The directions of magnetization changed systematically as illustrated by the orthogonal vector diagrams (Fig. 2). All samples displayed at least two components of magnetization. Component 1 is stable up to $100 \mathrm{Oe}$, and Component 2 is evident at higher demagnetizing fields. In some samples (e.g., Fig. 2A), the initial demagnetization step erased an additional component with a distinctly different direction. Because of its very low stability, this component, probably acquired during storage, will not be discussed further.

Figure 3 displays the distribution of inclinations for the NRM and the two prevalent components. The NRM has a wide range of inclination values, probably due to the effect of viscous magnetization. The components observed upon demagnetization have a tighter Gaussian distribution. Component 1 is, with one exception, of normal polarity and has an average inclination of $45.0^{\circ}$. Component 2 , on the other hand, has a negative inclination for all but two samples, with a mean of $-45.6^{\circ}$. The polarities of each component are plotted stratigraphically in Figure 4.

\section{Discussion}

Given the paleontological constraints, the reversal pattern of Component 1 is clearly incompatible with the expected polarity sequence (see Fig. 4). Correlation of Component 2 with the magnetic time scale would require either a variable and extremely fortuitous sedimentation rate or the presence of strategically placed hiatuses. Remagnetization is another possibility, suggested by the almost exclusive presence of one polarity in each component. Whatever the reason for the lack of correlation, it is not due to reliability of the data, for they are of superb quality.

\section{SITE 538}

\section{Results}

The NRM intensities of the samples from Hole 538A range over one order of magnitude with a mean value of $6.18 \times 10^{-6} \mathrm{emu} / \mathrm{cm}^{3}$. The 11 samples collected shipboard were demagnetized at 50, 100, and $200 \mathrm{Oe}$, followed by thermal demagnetization at 220,300, 400, 500 , and $550^{\circ} \mathrm{C}$. Except for three samples that displayed a consistent direction of magnetization, all samples had two components which could be clearly identified from orthogonal vector diagrams.

As Figure 5A,B illustrates, switching from thermal to AF demagnetization did not usually change the observed direction of magnetization. In some cases, however, the initial heating step removed a normal compo-
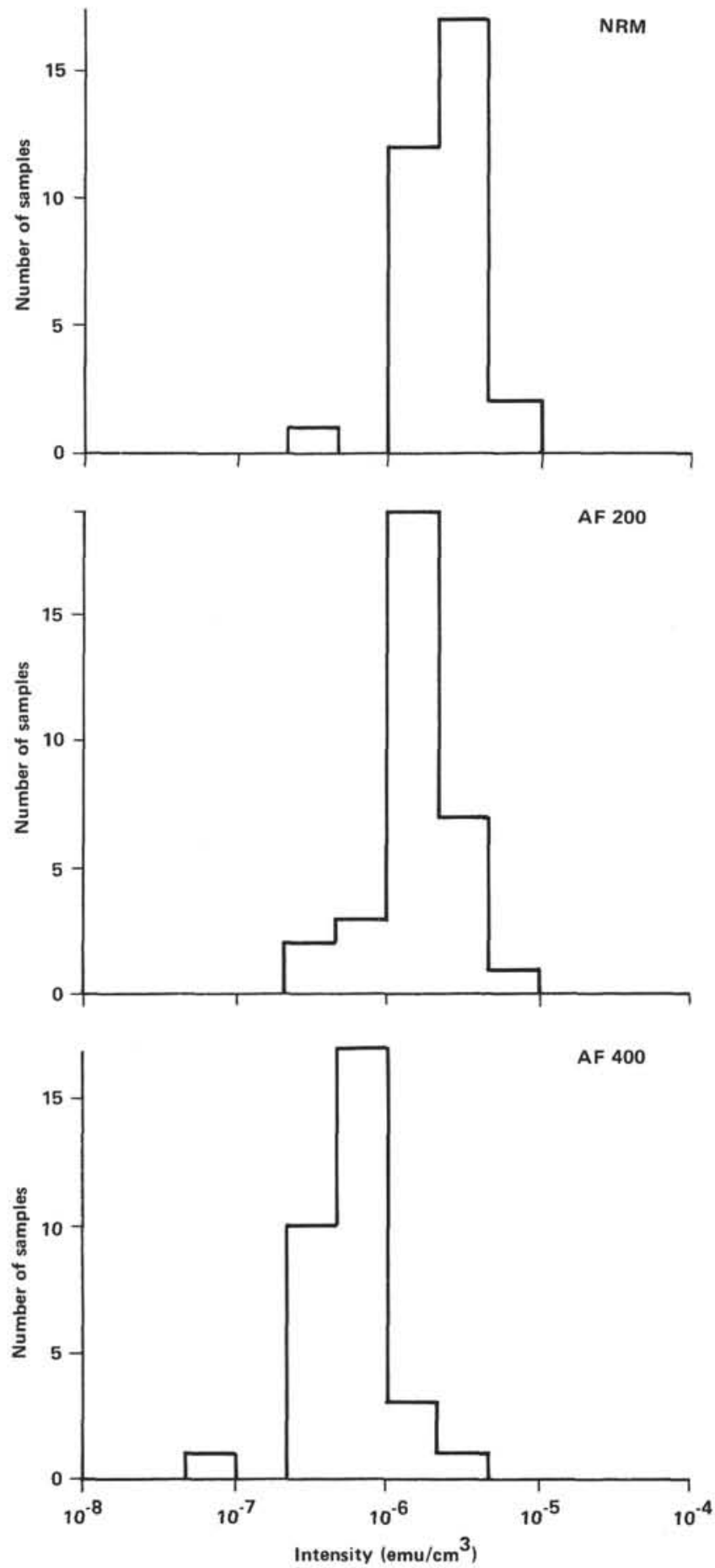

Figure 1. Distribution of NRM intensities and intensities after demagnetization to 200 and 400 Oe for the thirty-two samples from Site 536.

nent which alternating fields had been unable to erase (see Fig. 5C). For this reason, the five additional samples collected postcruise were demagnetized at $220^{\circ} \mathrm{C}$ before AF demagnetization at 100, 200, 300, and if necessary $400 \mathrm{Oe}$. All but one of these samples displayed two components of magnetization (see Fig. 5D).

Figure 6 illustrates the distribution of inclinations for the NRM, low stability component (1), and high stability component (2). Note that Component 1 , erased by 


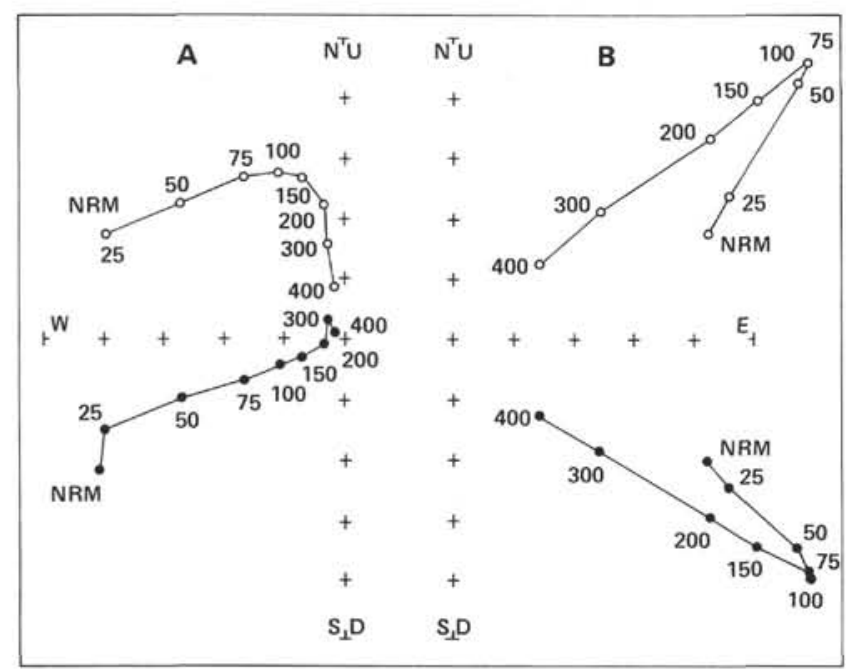

Figure 2. Exemplary orthogonal vector diagrams for Site 536. A, diagram for 536-9-3, $31 \mathrm{~cm}$; B, diagram for 536-9-5, $66 \mathrm{~cm}$. Closed circles represent north versus east component; open circles indicate up versus east component. Numbers show peak alternating field in oersteds.
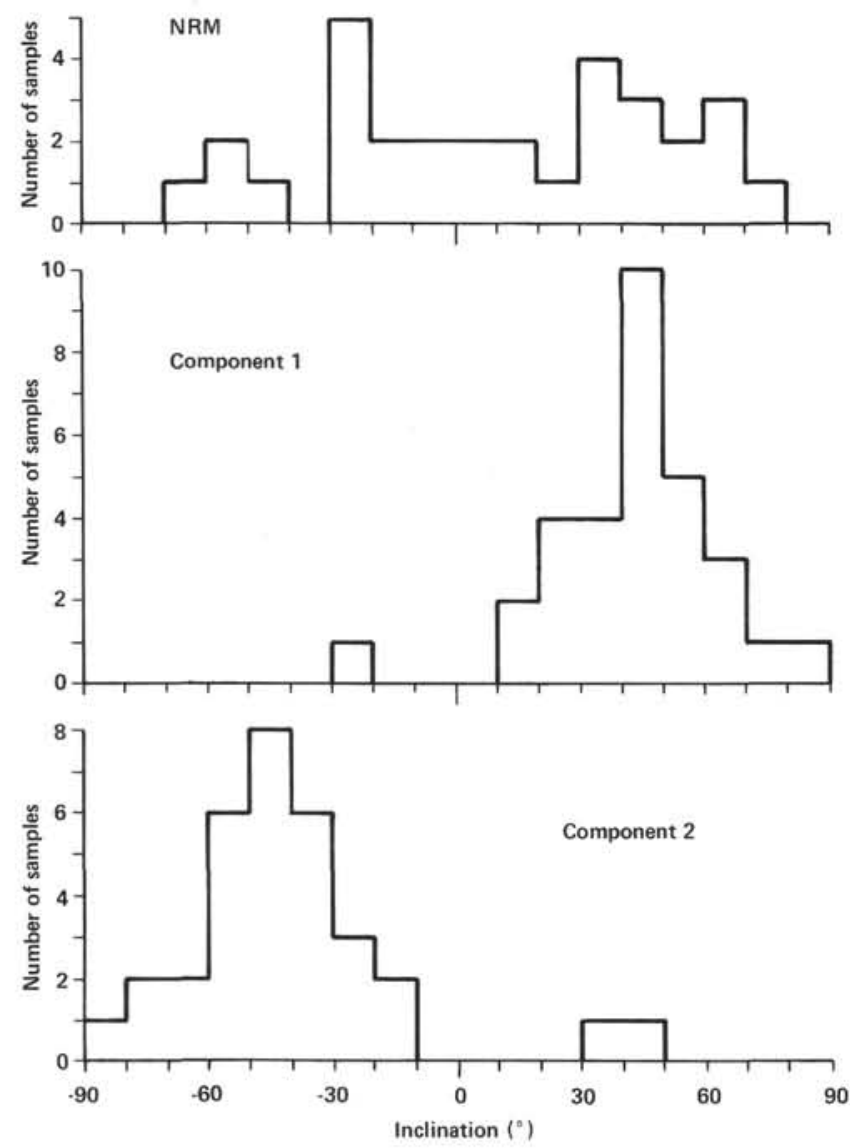

Figure 3. Distribution of inclinations for the NRMs and the two components of magnetization for samples from Site 536.

demagnetization to $100 \mathrm{Oe}$ or $220^{\circ} \mathrm{C}$, is in all cases of normal polarity. It is most likely an overprint acquired during the present normal polarity epoch. Component 2 is of both normal and reverse polarity and seems to rep-

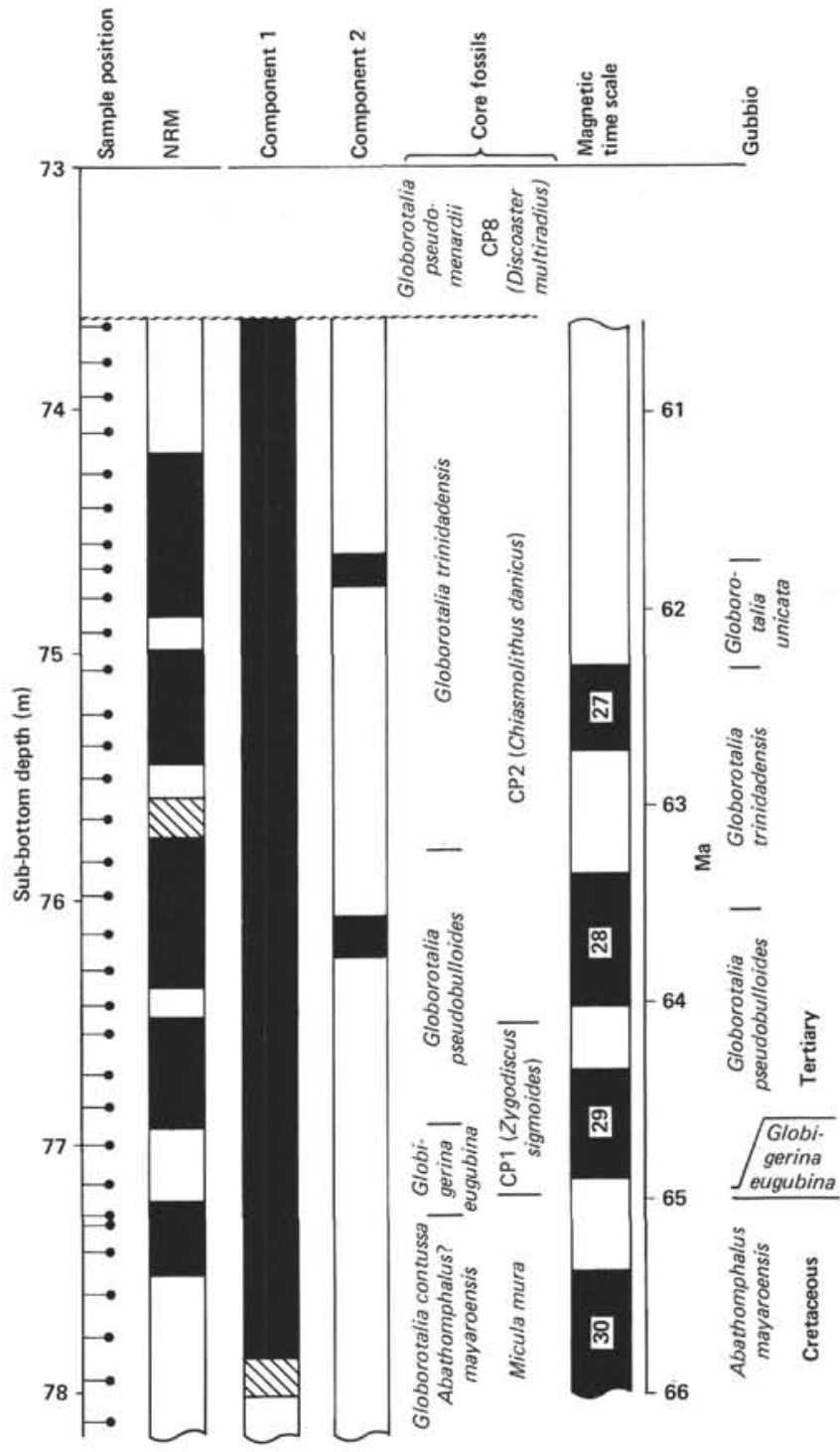

Figure 4. Comparison of the magnetic stratigraphy of Site 536 components (left) with the magnetic time scale after LaBrecque et al., 1977 (right). Biostratigraphy from the cores (site chapter, Site 536, this volume) and from Gubbio, Italy (Premoli Silva, 1977) are used to make the comparison. Black indicates normal polarity; white, reverse; hachured, indeterminate.

resent the original magnetization. Strong evidence for this comes from comparing declinations within groups of samples that were oriented relative to each other. In five cases, two or more samples were taken from the same piece of core or uniquely fitting, adjoining pieces in such a way that declinations as well as inclinations should agree. The groups of relatively oriented samples are indicated by brackets in Table 1. Consistent or antipodal directions of Component 2 are observed in most cases, a strong argument for this component being the primary one.

\section{Discussion}

In Figure 7, the inclinations of Component 2 are plotted stratigraphically. The "?" zone represents the $30 \mathrm{~cm}$ portion of the core unavailable for paleomagnetic sampling. Two foraminiferal zones (Globorotalia pseu- 


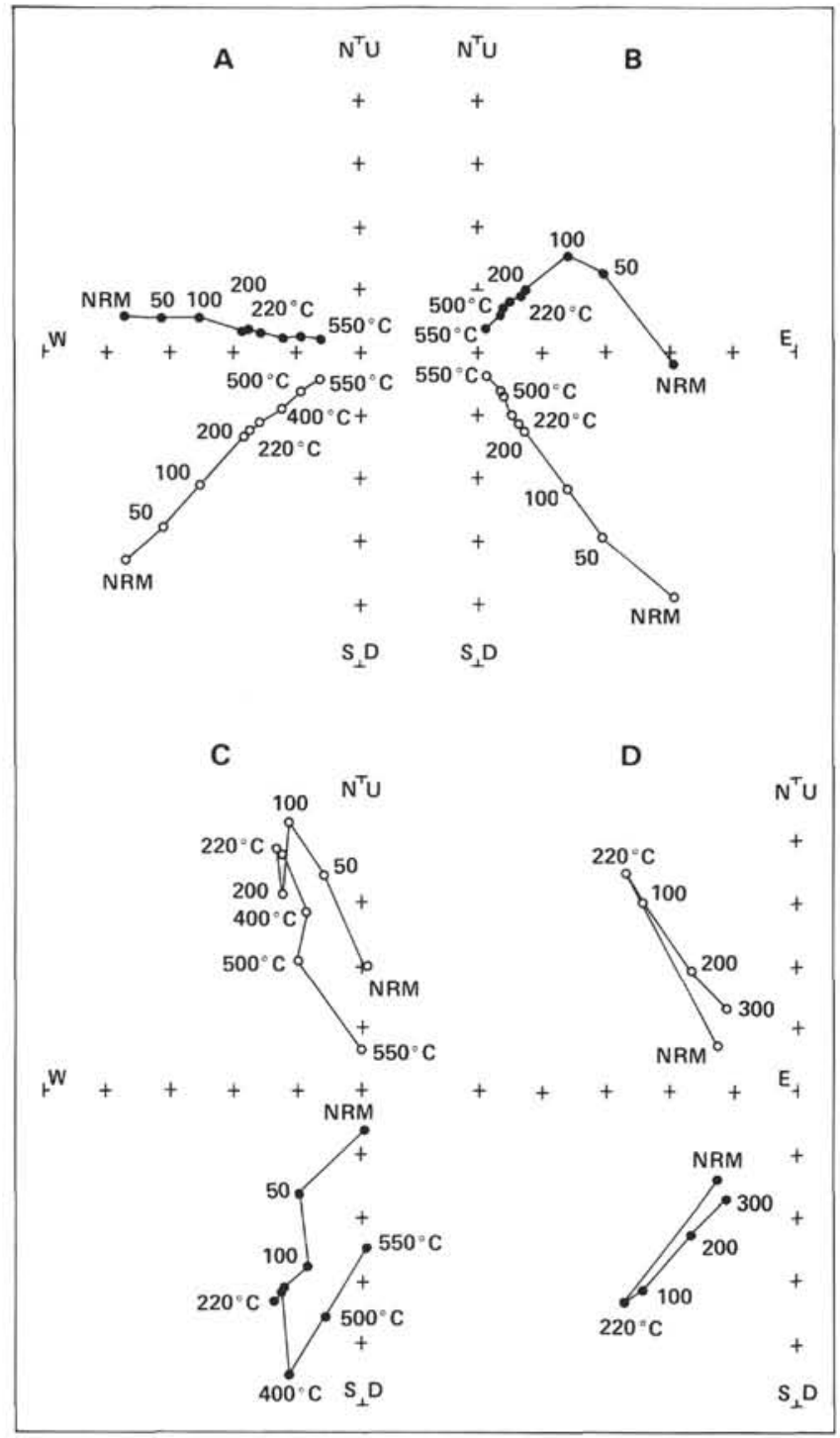

Figure 5. Orthogonal vector diagrams for Hole 538A. Closed circles represent north versus east component; open circles, up versus east component. Numbers indicate peak alternating field in oersteds unless thermal demagnetization is indicated by " " $\mathrm{C}$." A. One component of magnetization; 538A-20-5, $75 \mathrm{~cm}$. B. Two component magnetization, typical for most samples; $538 \mathrm{~A}-20-5,50 \mathrm{~cm}$. C. Removal of additional normal component upon changing from alternating field to thermal demagnetization; $538 \mathrm{~A}-20-6,24 \mathrm{~cm}$. D. Typical plot for samples demagnetized thermally before alternating fields were applied; 538A-20-6, $14 \mathrm{~cm}$.

dobulloides and G. trinidadensis) occur within the sampled interval (Premoli Silva, 1981, pers. comm.), necessitating that the reversal pattern include Anomaly 28 . However, until the boundary between the foraminiferal zones is specifically located, the observed reversal stratigraphy can not be uniquely correlated with the Danian portion of the magnetic time scale. Two possible correlations are shown in Figure 7, the left one making use of the observation that Anomaly 27 may consist of a triplet (Roggenthen and Napoleone, 1977). Both correlations require significant variations in sedimentation rate during deposition. Magnetically this section cannot be
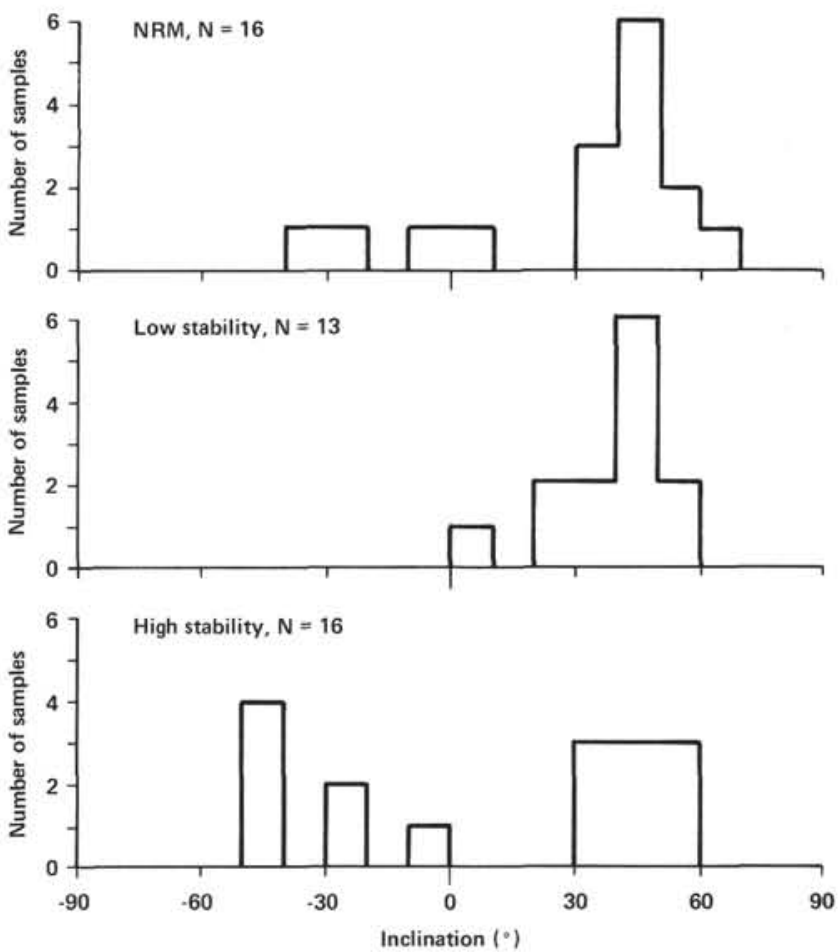

Figure 6. Distribution of inclinations for the NRMs and two components of magnetization for samples from Hole 538A.

Table 1. Components of magnetization for samples from Hole 538A.

\begin{tabular}{|c|c|c|c|c|c|}
\hline \multirow{2}{*}{$\begin{array}{c}\text { Sample } \\
\text { (Core-section, } \mathrm{cm} \\
\text { from top of section) }\end{array}$} & \multirow{2}{*}{$\begin{array}{l}\text { Sub-bottom } \\
\text { depth } \\
\text { (m) }\end{array}$} & \multicolumn{2}{|c|}{ Component 1} & \multicolumn{2}{|c|}{ Component 2} \\
\hline & & Decl. & Incl. & Decl. & Incl. \\
\hline$-20-4,113$ & 179.13 & 331.4 & 44.4 & 116.9 & -22.5 \\
\hline$-20-4,127$ & 179.27 & 211.3 & 6.2 & 143.4 & -29.4 \\
\hline ᄂ20-4, 145 & 179.45 & - & - & 297.6 & 55.9 \\
\hline $20-5,7$ & 179.57 & 348.0 & 35.3 & 262.7 & 50.4 \\
\hline$-20-5,19^{\mathrm{a}}$ & 179.69 & 284.6 & 42.8 & 124.4 & -44.0 \\
\hline$-20-5,26$ & 179.76 & 279.0 & 37.9 & 131.0 & -40.2 \\
\hline$L_{20-5,30^{\mathrm{a}}}$ & 179.80 & - & - & 303.4 & 49.4 \\
\hline$-20-5,44^{\mathrm{a}}$ & 179.94 & 3.7 & 51.8 & 20.9 & 47.4 \\
\hline$\llcorner 20-5,50$ & 180.00 & 143.1 & 27.4 & 36.3 & 45.3 \\
\hline$-20-5,75$ & 180.25 & - & - & 280.9 & 38.5 \\
\hline ᄂ20-5, 96 & 180.46 & 218.2 & 28.4 & 256.9 & 36.2 \\
\hline $20-5,113$ & 180.63 & 185.8 & 43.5 & 216.4 & 30.9 \\
\hline$\Gamma^{20-6,11}$ & 181.11 & 191.2 & 40.1 & 82.9 & 50.3 \\
\hline$-20-6,14^{a}$ & 181.14 & 37.1 & 48.4 & 223.9 & -43.7 \\
\hline$-20-6,21^{\mathrm{a}}$ & 181.21 & 28.9 & 52.4 & 97.7 & -6.2 \\
\hline ᄂ $20-6,24$ & 181.24 & 31.0 & 45.2 & 198.9 & -44.5 \\
\hline
\end{tabular}

a Samples collected postcruise and demagnetized in a different sequence of steps than the original 11 samples.

correlated with the Danian/Maestrichtian section at Site 536 .

\section{SUMMARY}

The paleomagnetic data from the Danian/Maestrichtian section at Site 536 and the Danian section at Hole $538 \mathrm{~A}$ are of high quality, but neither section can be uniquely correlated with the magnetic time scale. The lack of correlation may be due to a variable sedimentation rate, including non-deposition. At Site 536 remag- 


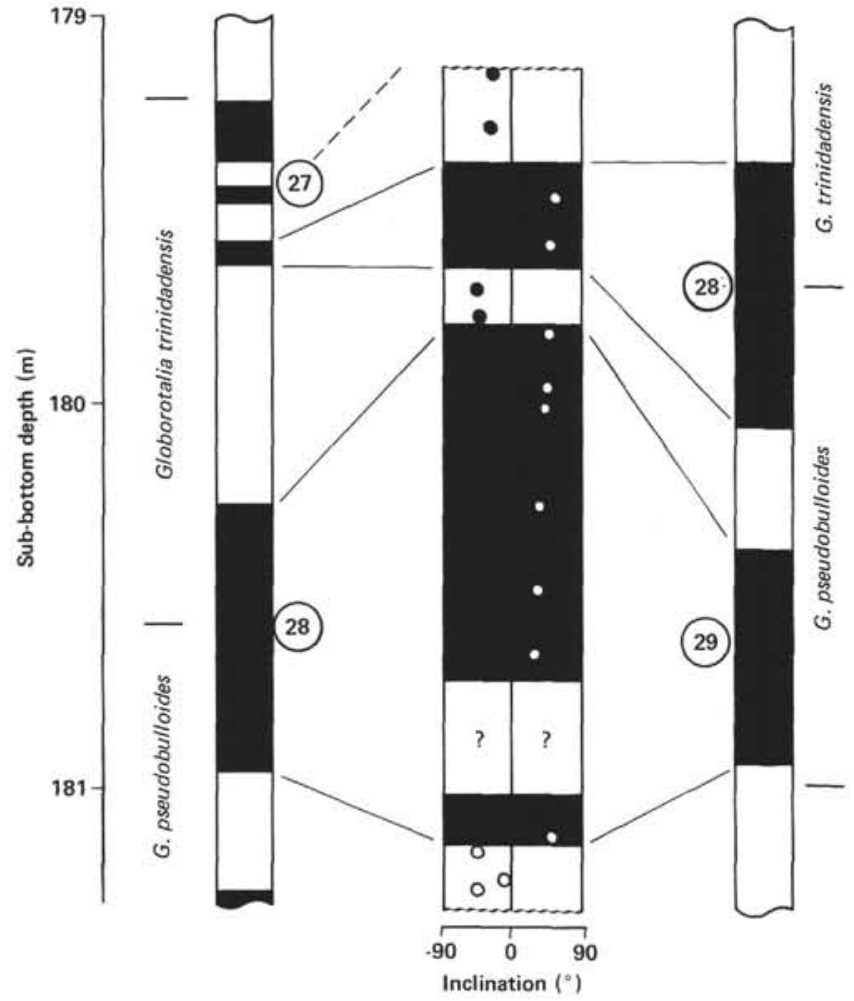

Figure 7. Two possible correlations of the magnetic stratigraphy of Hole 538A to the magnetic time scale after LaBrecque and others, 1977. Dots indicate sample positions; "?," unsampled interval. Circled numbers correspond to marine magnetic anomaly sequence. Black represents normal polarity; white, reverse polarity.

netization is also a possibility. A unique correlation of the reversal stratigraphy of Hole 538A may be possible should detailed paleontological data become available.

\section{ACKNOWLEDGMENT}

This work was supported by the University of Texas at Austin. University of Texas Institute for Geophysics Contribution No. 569.

\section{REFERENCES}

Alvarez, L. W., Alvarez, W., Asaro, F., and Michel, H. V., 1980. Extraterrestrial cause for the Cretaceous/Tertiary extinction: Experimental results and theoretical interpretation. Science 208: 1095-1108.

Hsü, K. J., LaBrecque, J. L., et al., 1984. Init. Repts. DSDP, 73: Washington (U.S. Govt. Printing Office).

LaBrecque, J. L., Kent, D. V., and Cande, S. C., 1977. Revised magnetic polarity time scale for Late Cretaceous and Cenozoic time. Geology, 5:330-335.

Larson, P. A., and Opdyke, N. D., 1979. Paleomagnetic results from Early Tertiary/Late Cretaceous sediments of Site 384. In Tucholke, B. E., Vogt, P. R., et al. 1979. Init. Repts. DSDP, 43: Washington (U.S. Govt. Printing Office), 785-787.

Lerbekmo, J. F., Evans, N. E., and Baadsgaard, H., 1979. Magnetostratigraphy, biostratigraphy and geochronology of Cretaceous/ Tertiary boundary sediments, Red Deer Valley. Nature, 279:26-30.

Lindsay, E. H., Butler, R. F., and Johnson, N. M., 1981. Magnetic polarity zonation and biostratigraphy of Late Cretaceous and $\mathrm{Pa}-$ leocene continental deposits, San Juan Basin, New Mexico. Am. J. Sci., 281:390-435.

Moore, T. C., Rabinowitz, P. D., et al., 1984. Init. Repts. DSDP, 74: Washington (U.S. Govt. Printing Office).

Premoli Silva, I., 1977. Upper Cretaceous/Paleocene magnetic stratigraphy at Gubbio, Italy. II. Biostratigraphy. Geol. Soc. Am. Bull., 88:371-374.

Roggenthen, W. M., and Napoleone, G., 1977. Upper Cretaceous/Paleoncene magnetic stratigraphy at Gubbio, Italy. IV. Upper Maastrichtian/Paleocene Magnetic Stratigraphy. Geol. Soc. Am. Bull., 88:378-382.

Thierstein, H. R., and Okada, H., 1979. The Cretaceous/Tertiary boundary event in the North Atlantic. In Tucholke, B. E., Vogt, P. R., et al., 1979. Init. Repts. DSDP, 43: Washington (U.S. Govt. Printing Office), 601-616.

Date of Initial Receipt: March 11, 1983

Date of Acceptance: October 24, 1983 